\title{
Energy Efficiency - Indoor Air Quality Dilemma in Educational Buildings: A Possible Solution
}

\author{
Liva ASERE $^{1 *}$, Andra BLUMBERGA ${ }^{2}$ \\ ${ }^{1,2}$ Institute of Energy Systems and Environment, Riga Technical University, Azenes iela 12/1, Riga, \\ LV-1048, Latvia
}

\begin{abstract}
The energy efficiency - indoor air quality dilemma is well known and the main drawback to operate the mechanical ventilation is electricity costs as concluded from previous studies. Educational buildings are one of the places where future taxpayers spend a lot of time. This paper aims to study an alternative solution on how to reduce energy efficiency indoor air quality dilemma in educational buildings by adopting systems that use renewable energy sources. A typical education building in Latvia is taken as a case study by changing it from a consumer to prosumer. This building type has a specific electricity usage profile that makes the choice of photovoltaics (PV) power quite challenging so the various power options have been analysed and used for an electricity solution. Also, the more decentralised preference is chosen - disconnect from a public heating provider and using a local system with a pellet boiler. Educational buildings using PV can reduce the electricity tariff, but the payback periods are still not very satisfactory without subsidies. The average electricity tariff per month varies between scenarios and the best one is for the scenario with $30 \mathrm{~kW}$ installed power. The educational building partly using $16 \mathrm{~kW}$ PV system reduces not only its bill for electricity but also reduces $\mathrm{CO}_{2}$ emissions by around 36 tons. The education buildings as energy prosumers using renewable energy sources are reducing GHG emissions by having high indoor air quality.
\end{abstract}

Keywords - educational buildings; energy efficiency; indoor air quality; prosumers; renewable energy sources; GHG emissions.

\section{INTRODUCTION}

The largest energy consumers in Europe are buildings that account for approximately $40 \%$ of EU energy consumption and $36 \%$ of $\mathrm{CO}_{2}$ emissions in the European Union [1], [2]. EU sets three main aims till 2050 with two steps in the 2020 and 2030 (see Table 1). The aim to cut greenhouse gas emissions is already fulfilled but the goal in regard to share of renewable energy and improvement in energy efficiency are not yet fulfilled.

EU has set the target for EU countries to make energy efficient renovations annually in at least $3 \%$ of buildings owned and occupied by central governments. Latvia in a 2018 report [6] has achieved its annual target in terms of renovated floor area. As a sustainable approach to improving the energy performance of existing buildings, retrofits have become popular for the past decades. It is vital to improve energy performance of buildings, therefore, reducing greenhouse gas emissions by building refurbishment and substituting electricity production from fossil fuels with renewable sources. The last decade has introduced energy efficiency as a widespread topic. Building location, orientation, size and height are spatial geometric building features that define

${ }^{*}$ Corresponding author.

E-mail address: liva.asere@rtu.lv 
the relationship with the local environment: sun, wind and also the surrounding buildings [7]. These features and their relationship should be considered before adopting energy efficiency measures as well as renewable energy resource usage for energy gains.

\begin{tabular}{|c|c|c|c|}
\hline Years & 2020 & 2030 & 2050 \\
\hline $\begin{array}{l}\text { Cuts in } \\
\text { greenhouse } \\
\text { gas emissions }\end{array}$ & 20 & 40 & $\begin{array}{l}80- \\
100\end{array}$ \\
\hline $\begin{array}{l}\text { Share for } \\
\text { renewable } \\
\text { energy }\end{array}$ & 20 & 32 & 100 \\
\hline $\begin{array}{l}\text { Improvement } \\
\text { in energy } \\
\text { efficiency }\end{array}$ & 20 & 32.5 & 41 \\
\hline
\end{tabular}

The results of the paper [8] show that ventilation flow needs to be checked before commencing building renovation. Therefore, this estimation would show the real effect that could be achieved while maintaining proper air quality before the building modernization is under consideration. Improved airtightness of the building envelope introduces the need for higher ventilation rates. The operation of mechanical ventilation systems provides comfortable climate conditions as well as lead to a higher energy bill. At one point, the systems are not working at all to save money and indoor air quality decreases [9], [10]. Bad indoor air quality can affect not only students in a school environment but also office workers [11] and doctors in health institutions [8]. This creates the conflict between energy efficiency and indoor air quality and is considered a dilemma that is presented by various authors [12]-[17] and is still a challenge within the building sector. We cannot neglect the true purpose of a building: to provide the occupants with a comfortable and healthy indoor environment in spite of the risk of higher energy consumption. There should be a possibility to use renewable energy sources to reduce grid energy consumption.

This paper aims to study alternative solutions on how to reduce energy efficiency - indoor air quality dilemma in educational buildings.

The introduction presents the European Union's and Latvia's aims in building energy field and the energy efficiency - indoor air quality dilemma. Literature review reveals information about the educational buildings' environments, renewable energy sources and prosumers. The study follows the methods adopted in the research. The results are presented in Section 4 and the research is summed up in conclusions.

\section{LiteratURE REVIEW}

\subsection{Educational Buildings' Environments}

Students' health and well-being are seriously affected by the environment of school buildings physical and non-physical limitations [18]. Students are growing up and are more sensitive to poor indoor air quality in school buildings [19]. Consequently, these buildings are a fundamental element of society. Classrooms have a high occupancy rate and buildings use different heating, ventilation and air conditioning systems to achieve and maintain nourishing indoor air quality levels. All these systems' maintenance costs are quite expensive and as concluded from previous studies - the main drawback operating the mechanical ventilation [20]. There are cases [10] when the systems are more likely not working and the indoor air quality in school buildings after energy 
efficiency measures have been implemented is very low and that affects students' health, comfort and performance conditions [21], [22].

\subsubsection{Solar Energy}

Solar energy technologies are rapidly evolving in Europe and worldwide and are replacing fossil energy technologies, thus helping to reduce greenhouse gas emissions. Solar energy has enormous potential, very low maintenance and service costs, and also the equipment prices have fallen significantly in recent years. Photovoltaics are best known as a method for generating electric power by using solar cells to convert energy from the sun into a flow of electrons by the photovoltaic effect. Solar cells produce direct current electricity from sunlight which can be used to power equipment or to recharge a battery. Solar photovoltaic power generation has long been seen as a clean energy technology which draws upon the planet's most plentiful and widely distributed renewable energy source - the sun.

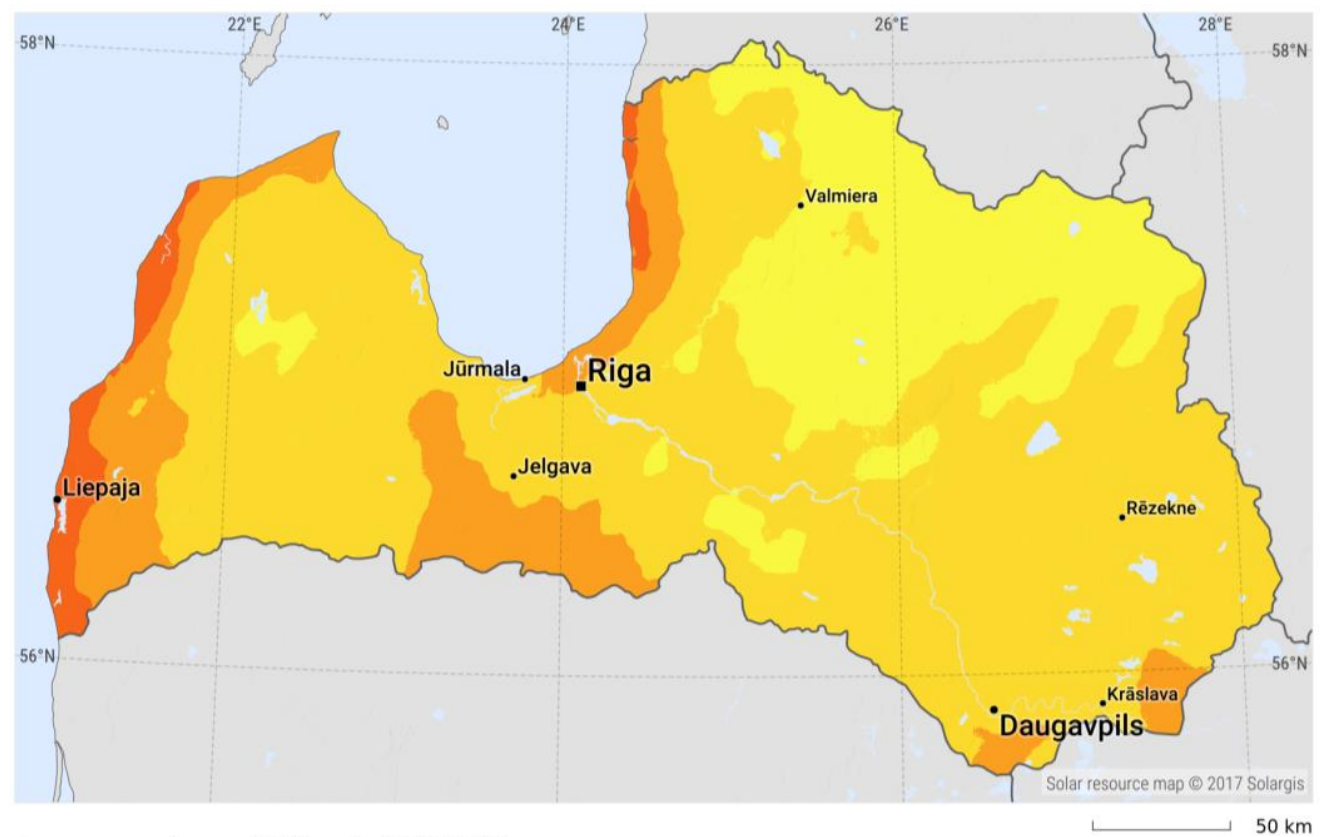

Average annual sum of $\mathrm{GHI}$, period 1994-2016

$950 \quad 1000 \quad 1050 \quad \mathrm{kWh} / \mathrm{m}^{2}$

Fig. 1. Global horizontal irradiation in Latvia [23].

Photovoltaics represent around $4.3 \%$ [24] of Europe's electricity demand and $2.9 \%$ [25] on the global scale. The installed capacity of PV modules in Latvia is $1.962 \mathrm{MW}$ in 2018 [26]. It produced only $0.017 \%$ of the total electricity demand in Latvia [27]. Data shows that photovoltaic power (PV) potential in Latvia is $950-1100 \mathrm{kWh} / \mathrm{m}^{2}$ depending on geographical location but that does not include optimum tilt of PV modules (Fig. 1). 


\subsubsection{Biomass}

Around $56 \%$ [28] of Latvia's area is covered by woodland. Every year the trees are cut down and reforestation is carried out. Over the years, firewood has been the most popular fuel for heat production in Latvia. Nowadays, the industrial consumption of wood for heating both for heat production and for combined electricity and heat production in cogeneration plants is growing rapidly in many European countries [29].

Wood pellet boilers are more economical and automated than using firewood. Wood pellets are being produced almost all over Europe, however, the Baltic countries produce primarily for export rather than local consumption. From 2012 till 2016 Latvia was the EU's third-largest producer and the top exporter of wood pellets [29], [30].

\subsubsection{Prosumers}

Energy transition has three main objectives: to increase energy efficiency, to deploy renewable energy, and most importantly to reduce GHG emissions. Prosumers (producers - consumers) [31], [32] can be the main players of a more decentralised sustainable energy system by fulfilling parts of their energy needs through self-produced energy with renewables.

Toffler introduced the term 'prosumer' in 1981 [33]. The prosumers have a large potential because of micro-generation technologies that are used in the market for producing and storing electricity and heat [34].

The definition of prosumer contains three types as defined by the International Energy Agency (IEA) [31]:

- prosumers commercially sell "a large share of the power generated into the grid, while continuing to purchase electricity from the utility as well";

- prosumers self-consume, by continuing "to purchase power from the grid, but reducing the amount purchased by using their PV system to supply a portion of their own electricity needs (and potentially get remunerated for any surplus generation that they may inject into the grid)";

- self-providers (or off-grid prosumers) that "supply $100 \%$ of their electricity needs with PV, storage, and other technologies".

Worldwide PV prosumers form an important part of the total installed solar PV capacity and the trend is increasing. Solar photovoltaics are a growing interest everywhere because product innovation and performance improvements give consumers a wider choice. The benefits also include that the costs for these systems continuously decreases. The PV prosumers might be one of the main players in energy transition because they consume most of the generated electricity and the grid is fed by less additional electricity. PV prosumer systems must include electricity and heat storage technologies and heat pumps to accomplish the highest possible self-consumption shares [35]. Some authors assume that it is expected to achieve grid-parity in the remaining residential electricity markets [36].

\section{Methodology}

\subsection{Typical Educational Building as a Consumer}

For further analysis, we use a school building (total heating area $5140 \mathrm{~m}^{2}$, volume $24000 \mathrm{~m}^{3}$ ) that works as a consumer and is located in the city Saldus. The average heating demand is $329 \mathrm{MWh}$ per season. The electricity consumption profile is visualized in Table 2. 
TABLE 2. ELECTRICITY CONSUMPTION PROFILE

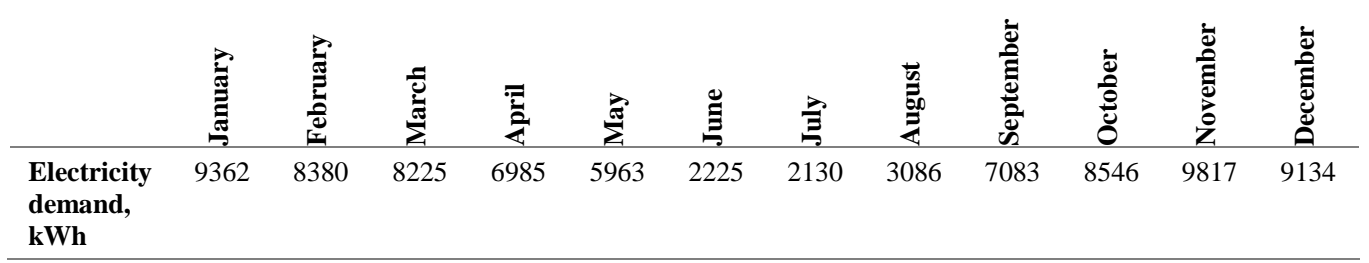

The various photovoltaics and wood pellet boiler proposals will be made to find the best scenario for educational building change from consumer to prosumer.

\subsubsection{Electricity Solution}

Education buildings are very specific in terms of energy consumption because in the summer holidays when solar radiation is the highest, the school buildings are not being used at the usual workload. The proposed electricity solution is the photovoltaic panels that are calculated to cover electricity demand below the maximum in summer months $(\sim 2100 \mathrm{kWh} / \mathrm{month})$. This solution allows to mainly use all the generated electricity immediately.

The following formula was used to estimate the generated electricity [37]:

$$
E=A \cdot R \cdot H \cdot P R,
$$

where

E energy, kWh;

A total solar panel area, $\mathrm{m}^{2}$;

$R \quad$ solar panel yield or efficiency (17.5\% [38]);

$H \quad$ annual average solar radiation on tilted panels $\left(1237 \mathrm{kWh} / \mathrm{m}^{2}\right.$ at an optimal tilt);

$P R \quad$ performance ratio, the coefficient for losses (0.75).

The electricity will be fed into the grid on weekends (the produced electricity that covers around 6 days per month) and variable $\%$ of overall monthly production.

\subsubsection{Electricity Tariff}

Based on the data from Saldus, the average monthly electricity bill was calculated before and after installing the solar panels of various power.

The electricity tariff is made by the sum of electricity price, fixed distribution tariff, variable distribution tariff, fixed mandatory procurement component (MPC) tariff, variable MPC tariff and value-added tax.

Nord Pool LV dynamic average electricity stock price in the prior 12 months at 2020/03 is $0.04446 \mathrm{EUR} / \mathrm{kWh}[39]$. The education building is a consumer that uses a three-phase connection with input protection device of $125 \mathrm{~A}$.

The distribution tariff is 7.25 EUR/A/year [40]. The variable distribution tariff is 0.04422 EUR/kWh [40].

The fixed MPC tariff is 4.38 EUR/A/year [41]. The variable MPC tariff 0.01476 EUR/kWh [41].

Value-added tax is applied to the final electricity bill (21\%).

The net payment scheme is applied to the micro-generator (power less than $11 \mathrm{~kW}$ ) [42]. Grid-connected electricity producers (over $11 \mathrm{~kW}$ ) is considered as power plant connection [43] 
so it can sell electricity by feeding it in the grid and afterwards taking it back from the distribution system by buying it. In calculations, the electricity price is considered constant for selling and buying operations. The variable MPC tariff is considered only for the amount of electricity that is taken from the grid.

\subsubsection{Capital and Maintenance Costs}

Capital costs include the sum of solar panels, inverter, cables, mounts, installation and documentation costs. The potential capital costs for overall system installation in Latvia varies starting from 1000 euro/kW. In our calculation 1100 euro/kW is used.

Electricity production from photovoltaics decreases by $0.9 \%$ per year. After 25 years photovoltaics manufactures guarantee $80 \%$ of the initial efficiency.

The payback time was calculated for three scenarios $-11 \mathrm{~kW}, 16 \mathrm{~kW}$ and $30 \mathrm{~kW}$.

\subsubsection{Heating Solution}

For a typical energy-efficient school building of $5140 \mathrm{~m}^{2}$, the proposed solution for heating and hot water supply is a wood pellet boiler $(400 \mathrm{~kW} \eta=0.92)$ with pellet container and auger for automatic supply of pellets from the container to the burner. Wood pellet $(4.8 \mathrm{kWh} / \mathrm{kg})$ consumption per year is estimated to be around 75 tons.

\subsubsection{Capital and Maintenance Costs}

The following costs are incurred for the building: capital costs of pellet boiler - 45000 euro; maintenance costs - 1640 EUR/pellet costs per year (75 t) - 12000 EUR/year.

The heating tariff directly affects the payback period and it can vary over the years. For calculations, the heating tariff in Saldus was used (68.80 EUR/MWh in 2020) [44].

\subsection{6. $\mathrm{CO}_{2}$ Emission Reduction}

The calculation of $\mathrm{CO}_{2}$ emission reduction is made by using $\mathrm{CO}_{2}$ emission intensity and data from potential amounts of electricity production in 25 years. The yearly PV energy production is forecasted to reduce by $0.9 \%$ per year and after 25 years reach around $80 \%$ of the first-year efficiency.

$$
E_{r}=E_{I} \cdot P V_{e} \cdot 10^{-6}
$$

where

$E_{r} \quad$ emission reduction, $\mathrm{tCO}_{2}$;

$E_{l} \quad$ emission intensity, $\mathrm{gCO}_{2} / \mathrm{kWh}$;

$P V_{e} \quad \mathrm{PV}$ production, $\mathrm{kWh}$.

$\mathrm{CO}_{2}$ emission intensity is $104.9 \mathrm{~g} \mathrm{CO}_{2} / \mathrm{kWh}$ from electricity generation in Latvia (2016) [45]. Public supplier provided heat $\mathrm{CO}_{2}$ intensity is not considered in the decrease of $\mathrm{CO}_{2}$ emissions.

\section{Results}

Yearly PV energy production is prognosed to be around $963 \mathrm{kWh} / \mathrm{kWp}$. The educational building that produces electricity (even partly) have decreased electricity tariff. The average electricity tariff per month varies between scenarios (Fig. 2) and the best one is for the scenario with $30 \mathrm{~kW}$ installed power, although almost half of the energy flows into the grid. 
$2020 / 24$

One needs to keep in mind that the generated amount of electricity in the first year will not be the same after 25 years. The PV panel producers guarantee $80 \%$ of efficiency at the end of the PV modules lifetime so the investment payback time should be as short as possible to get the best profit. Subsidies can reduce the payback time.

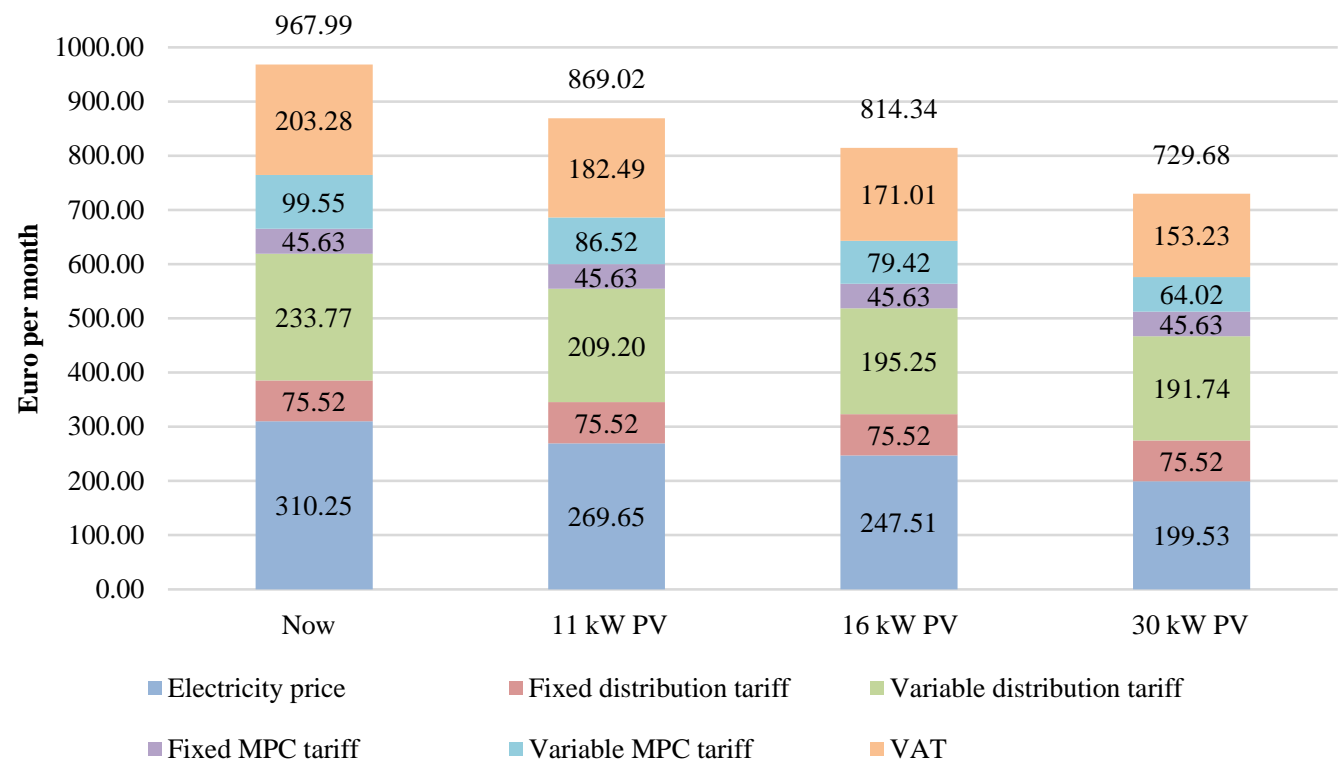

Fig. 2. The average monthly electricity bill before and after installation of solar panels.

Capital costs of a PV system and its investment payback time is visualized in Fig. 3. The payback time for $16 \mathrm{~kW} \mathrm{PV}$ is lower than both $11 \mathrm{~kW}$ and $30 \mathrm{~kW}$ systems but still, a payback time of almost 10 years is not a satisfactory result.

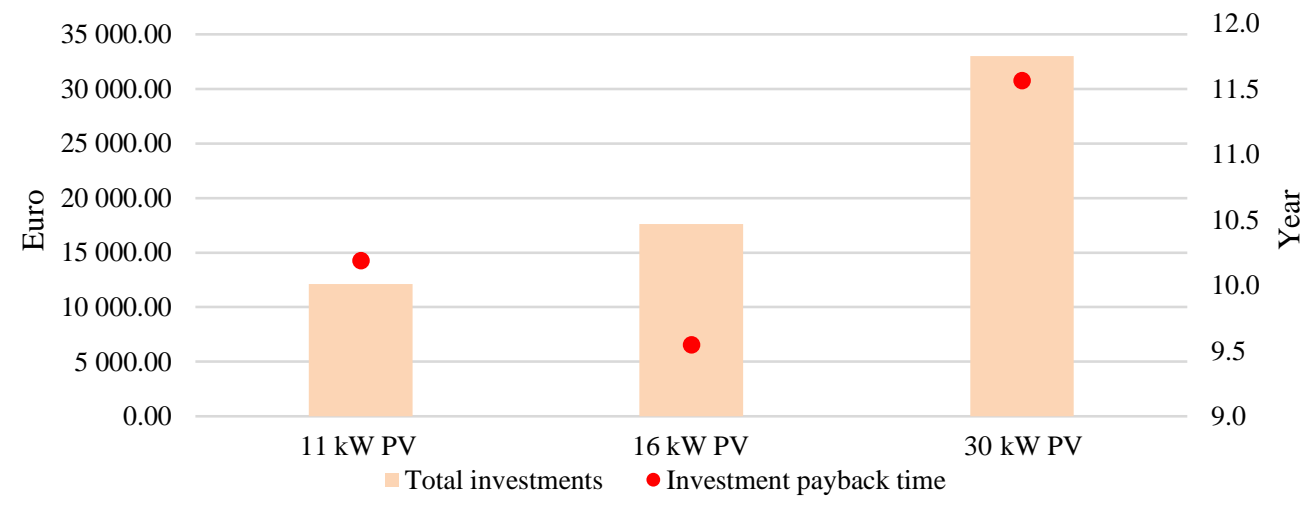

Fig. 3. Costs of PV system and payback time. 
The two situations are viewed in more detail - possible subsidies that cover $50 \%$ of capital costs and pellet boiler installation. The payback time can be reduced to less than 5 years for the first scenario and less than 6 years for the second scenario (Fig. 4).

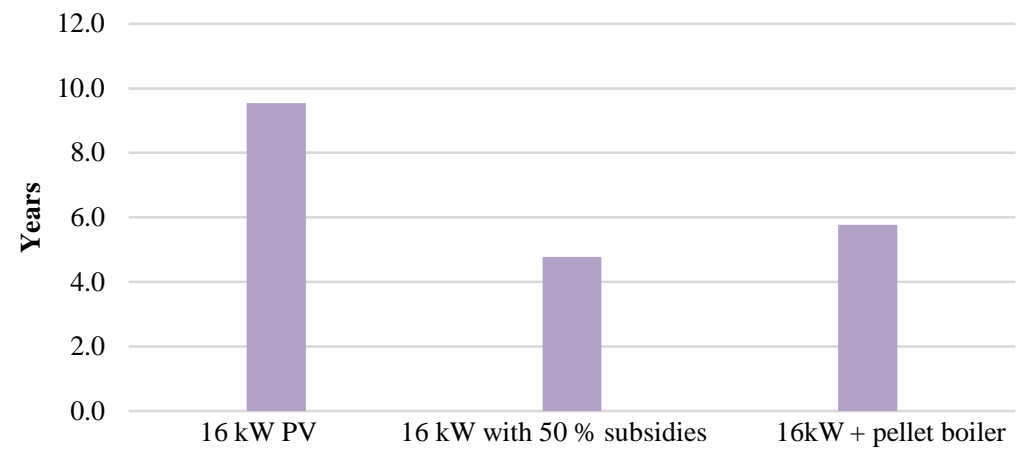

Fig. 4. Investment payback time.

Decrease of $\mathrm{CO}_{2}$ emissions by partly using solar energy instead of taking all electricity from grid is visualized in Fig. 5.

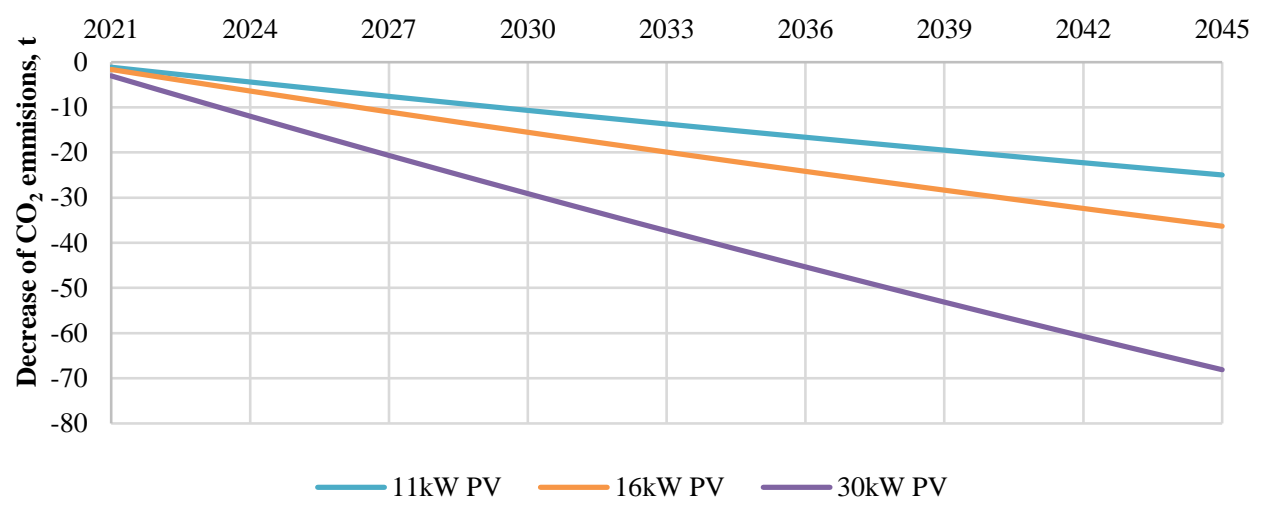

Fig. 5. Decrease of $\mathrm{CO}_{2}$ emissions.

The photovoltaic system of $16 \mathrm{~kW}$ can reduce around 36 tons of $\mathrm{CO}_{2}$ in its lifetime. The more power is generated by $\mathrm{PV}$, the larger decrease of $\mathrm{CO}_{2}$ emissions, however, the school building electricity consumption demand specifics show that systems over $16 \mathrm{~kW}$ feed into the grid more than $25 \%$ of generated energy.

\section{Conclusions}

A consumer usually receives heating and electricity from a public supplier. Grid-connected users can change as prosumers if the economic attractiveness is good enough. This process can 
give various benefits: fewer emissions, more energy is generated with renewable energy resources and higher possibility that mechanical ventilation will be used in the buildings.

The education building's daily energy usage profile is necessary to analyse the best solution for using the generated electricity immediately. The PV system of $16 \mathrm{~kW}$ could reduce the education building' average electricity costs by $16 \%$ or around 1844 euro per year. The higher the installed PV power, the lower the overall electricity tariff although a lot of it flows into the grid and is not consumed right away. In this situation, the possible variations of benefits are affected by Nord Pool market prices and should be further examined. For all analysed scenarios, the payback time of the PV panel installation costs is 9.5 to 11.6 years without any support. The payback time for $16 \mathrm{~kW}$ PV can be reduced less than 5 years if the subsidies are $50 \%$ of capital investments. The installation of the biomass boiler's payback time is around 4.2 years. As the heating costs will be lower these savings could be as a "subsidy" for PV panels. This option would help decrease the payback time of PV panels. The off-grid scenario was also considered but the school's electricity consumption profile and accumulator prices are not profitable at the current time. The outdoor $\mathrm{CO}_{2}$ reduction is less than 40 tons by installing $16 \mathrm{~kW}$ PV modules.

This research aims to find the possible solution for energy efficiency - indoor air quality dilemma in educational buildings. The usage of PV panels to partly produce the necessary electricity for the school building led to a decrease in the average electricity costs that usually is the main drawback for the operation of mechanical ventilation. The usage of PV panels and a pellet boiler is the possible solution for energy efficiency and indoor air quality dilemma so the students would have a qualitative school environment. Therefore these students would have better performance, the country would have professionals with better qualification and after all the higher GDP increase [20].

Electricity tariff changes are the key factor for changing mechanical ventilation workload. Educational buildings changing from consumers to prosumers gives the possibility to reduce the electricity tariff thus making it possible to make both arrows in the same direction $-\mathrm{CO}_{2}$ level decrease outdoors and indoors.

Further research will focus on the electricity prices from Nord Pool market data and how that can affect the usage time and the simple payback time. Also the installed PV system generated and calculated data should be analysed in the future.

\section{ACKNOWLEDGEMENT}

The research is funded by the Ministry of Economics of the Republic of Latvia, project "Improvement of building energy efficiency technologies (I-BEET)" project No. VPP-EM-EE-2018/1-0003.

\section{REFERENCES}

[1] Directive (EU) 2018/844 of the European Parliament and of the Council of 30 May 2018 amending Directive 2010/31/EU on the energy performance of buildings and Directive 2012/27/EU on energy efficiency (Text with EEA relevance). Official Journal of the European Union 2018:L 156/75.

[2] Energy Performance of Buildings Directive. Structural Survey 2005:23(1). https://doi.org/10.1108/ss.2005.11023aab.001

[3] European Commission. A Roadmap for moving to a competitive low carbon economy in 2050. Brussels: European Commission, 2011.

[4] European Commission. 2030 Climate \& Energy framework - Climate Action. 2030 Climate \& Energy Framework, 2018.

[5] European Environment Agency. Share of EU energy consumption from renewable sources, 2005-2050. 2019. 
[6] European Commission Report. Report from the Commission to the European Parliament and the Council. The application of Council Regulation 2157/2001 of 8 October 2001 on the Statute for a European Company (SE). Brussels: European Commission, 2010.

[7] Du X., Bokel R., van den Dobbelsteen A. Spatial configuration, building microclimate and thermal comfort: A modern house case. Energy and Buildings 2019:193:185-200. https://doi.org/10.1016/j.enbuild.2019.03.038

[8] Gładyszewska-Fiedoruk K., Krawczyk D. A. The possibilities of energy consumption reduction and a maintenance of indoor air quality in doctor's offices located in north-eastern Poland. Energy and Buildings 2014:85:235-245. https://doi.org/10.1016/j.enbuild.2014.08.041

[9] Asere L., Mols T., Blumberga A. Assessment of Indoor Air Quality in Renovated Buildings of Liepāja Municipality. Energy Procedia 2016:91:907-915. https://doi.org/10.1016/j.egypro.2016.06.257

[10] Csobod É., et al. SINPHONIE - Schools Indoor Pollution and Health Observatory Network in Europe - Final Report. Luxembourg: Publications Office of the European Union, 2014.

[11] Gladyszewska-Fiedoruk K. Survey Research of Selected Issues the Sick Building Syndrome (SBS) in an Office Building. Environmental and Climate Technologies 2019:23(2):1-8. https://doi.org/10.2478/rtuect-2019-0050

[12] Becker R., Goldberger I., Paciuk M. Improving energy performance of school buildings while ensuring indoor air quality ventilation. Building and Environment 2007:42(9):3261-3276. https://doi.org/10.1016/j.buildenv.2006.08.016

[13] Vasile V., et al. Indoor Air Quality - A Key Element of the Energy Performance of the Buildings. Energy Procedia 2016:96:277-284. https://doi.org/10.1016/j.egypro.2016.09.150

[14] Földváry V., et al. Effect of energy renovation on indoor air quality in multifamily residential buildings in Slovakia. Building and Environment 2017:122:363-372. https://doi.org/10.1016/j.buildenv.2017.06.009

[15] Ghita S. A., Catalina T. Energy efficiency versus indoor environmental quality in different Romanian countryside schools. Energy and Buildings 2015:92:140-154. https://doi.org/10.1016/j.enbuild.2015.01.049

[16] Dascalaki E. G., Sermpetzoglou V. G. Energy performance and indoor environmental quality in Hellenic schools. Energy and Buildings 2011:43(2-3):718-727. https://doi.org/10.1016/j.enbuild.2010.11.017

[17] Yang W., et al. Indoor air quality investigation according to age of the school buildings in Korea. Journal of Environmental Management 2009:90(1):348-354. https://doi.org/10.1016/j.jenvman.2007.10.003

[18] Baker L., Bernstein H. The Impact of School Buildings on Student Health and Performance. New York, NY: McGrawHill Research Foundation, 2012.

[19] d'Ambrosio Alfano F. R., et al. Indoor Environment And Energy Efficiency In Schools - Part 1. Brussels, 2010.

[20] Asere L., Blumberga A. Does energy efficiency-indoor air quality dilemma have an impact on the gross domestic product? Journal of Environmental Management 2019:262:110270. https://doi.org/10.1016/j.jenvman.2020.110270

[21] Wargocki P., Wyon D. P. Providing better thermal and air quality conditions in school classrooms would be costeffective. Building and Environment 2013:59:581-589. https://doi.org/10.1016/j.buildenv.2012.10.007

[22] Bakó-Biró Z., et al. Ventilation rates in schools and pupils' performance. Building and Environment 2012:48(1):215223. https://doi.org/10.1016/j.buildenv.2011.08.018

[23] SolarGIS. Solar resource maps and GIS data. 2020. [Online]. [Accessed 07.02.2020]. Available: https://solargis.com/maps-and-gis-data/download/latvia

[24] Arnulf J.-W. PV Status Report 2019. Luxembourg: Publications Office of the European Union, 2019.

[25] Masson G., Kaizuka I. IEA PVPS report - Trends in Photovoltaic Applications 2019. Paris: IEA, 2019.

[26] Eurostat. Electricity production capacities for renewables and wastes [Online]. [Accessed 27.05.2020]. Available: https://appsso.eurostat.ec.europa.eu/nui/show.do?dataset=nrg_inf_epcrw\&lang=en

[27] AS Augstsprieguma tīkls. Elektroenergijas tirgus apskats, AST. [Accessed 27.05.2020]. Available: http://www.ast.lv/lv/electricity-market-review

[28] Eurostat. Area of wooded land (source: FAO - FE) [Online]. [Accessed 27.05.2020]. Available: https://appsso.eurostat.ec.europa.eu/nui/submitViewTableAction.do

[29] Gathier G., Jossart J.-M., Calderon C. AEBIOM Statistical Report. Pellet Market Overview. European Bioenergy Outlook. Brussels: European Biomass Associaton, 2017.

[30] Eurostat. Eurostat celebrates Latvia - Product [Online]. [Accessed 27.05.2020]. Available: https://ec.europa.eu/eurostat/en/web/products-eurostat-news/-/EDN-20171118-1

[31] Rickerson W., et al. IEA-RETD Residential Prosumers-Drivers and Policy Options (Re-Prosumers). Paris: IEA, 2014.

[32] Flaute M., et al. Macroeconomic effects of prosumer households in Germany. International Journal of Energy Economics and Policy 2017:7(1):146-155.

[33] Toffler A. Future Shock: The Third Wave. Bantam Book, 1981.

[34] Oberst C. A., Schmitz H., Madlener R. Are Prosumer Households That Much Different? Evidence From Stated Residential Energy Consumption in Germany. Ecological Economics 2019:158:101-115. https://doi.org/10.1016/j.ecolecon.2018.12.014

[35] Keiner D., et al. Cost optimal self-consumption of PV prosumers with stationary batteries, heat pumps, thermal energy storage and electric vehicles across the world up to 2050. Solar Energy 2109:185:406-423. https://doi.org/10.1016/j.solener.2019.04.081 
[36] Breyer C., Gerlach A. Global overview on grid-parity. Progress in Photovoltaics: Research and Applications 2013:21(1):121-136. https://doi.org/10.1002/pip.1254

[37] Photovoltaic Software. How to calculate output energy of PV solar systems? 2019 [Online]. [Accessed 27.05.2020]. Available: https://photovoltaic-software.com/principle-ressources/how-calculate-solar-energy-power-pv-systems

[38] Wujek P., Sprawka P. New PV Micro-Modules on Standard Roof Tiles. Environmental and Climate Technologies 2019:23(2):338-346. https://doi.org/10.2478/rtuect-2019-0072

[39] 2020 Electricity Tariff Calculator Electroenergy Tariff Comparison [Online]. [Accessed 27.05.2020]. Available: https://www.elektroenergija.lv/en

[40] AS Sadales tīkls. AS Sadales tīkls, elektroenerǵijas sadales sistēmas pakalpojumu diferencētie tarifi no 2020.gada 1. janvāra (bez PVN) (JSC Sadales tīkls, differentiated tariffs for electricity distribution system services from January $\begin{array}{llllll}1,2020 & \text { (excluding } & \text { VAT)) }\end{array}$ https://www.sadalestikls.lv/uploads/2020/01/ST_tarifi_2020-labots.pdf (in Latvian)

[41] Elektrum. Mandatory procurement and capacity components : Electricity [Online]. [Accessed 27.05.2020]. Available: https://www.elektrum.lv/en/for-business/electricity/mandatory-procurement-and-capacity-components-1

[42] AS Sadales tikkls. Microgenerator connection [Online]. [Accessed 27.05.2020]. Available: https://www.sadalestikls.lv/en/to-customers/connections/microgenerator-connection

[43] AS Sadales tikls. Power plant connection [Online]. [Accessed 27.05.2020]. Available: https://www.sadalestikls.lv/en/to-customers/connections/producer-connections

[44] SPRK. Tarifi (Tariffs) [Online]. [Accessed 27.05.2020]. Available: https://www.sprk.gov.lv/content/tarifi-4 (in Latvian)

[45] EEA. CO2 emission intensity - European Environment Agency. 2017.
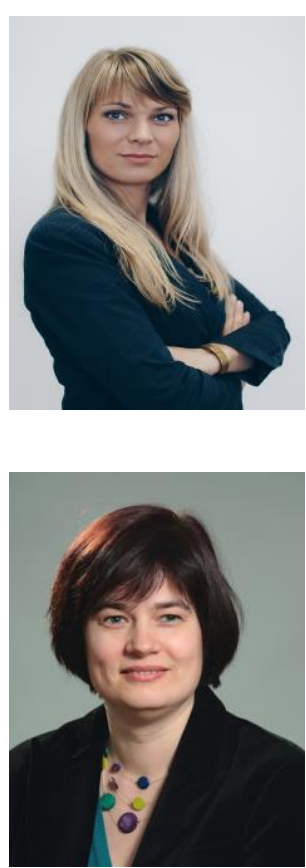

Liva Asere, M. sc., has obtained a Master's degree in Environmental Science at Riga Technical University (2014). She started her $\mathrm{PhD}$ studies at the doctoral programme Environmental Science of the Riga Technical University. The work experience includes working as a Researcher at Riga Technical University and as a Project Manager at environmental consulting company Vides Eksperti. Her main research interest is energy efficiency and indoor air quality dilemma in education buildings.

E-mail: liva.asere@rtu.lv

ORCID iD: https://orcid.org/0000-0001-7688-834X

Andra Blumberga, Dr. sc. ing., professor, works for Institute of Energy Systems and Environments, Riga Technical University since 2001. She has been working with energy efficiency since 1992. Her main research interest is energy efficiency both from technical and policy sides. She has managed many national and international research and other projects since 1999, e.g. "Assesment on energy efficiency and use of renewable energy sources in Latvia by 2020", "Climate Technology development modeling in energy sector", "Energy strategy 2030 for Latvia", "System Dynamics modeling for energy sector in Latvia". She has been working as the World Bank energy expert for development of the Green Investment Scheme in Latvia. She is an author of more than 80 publications and 14 monographs.

E-mail: andra.blumberga@rtu.lv

ORCID iD: http://orcid.org/0000-0002-4712-4794 